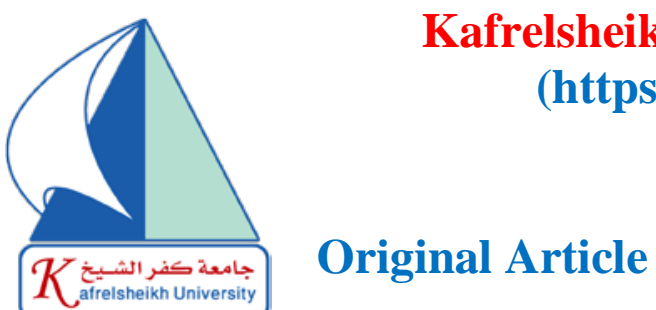

Received Oct 13, 2020

Accepted Nov 4, 2020

Published Jan 11, 2021

\title{
Relationship between reproductive efficiency and blood calcium level during transition period in dairy cows
}

\author{
Youssef Elseady $^{a^{*}}$; Ahmed Elmahdy ${ }^{b}$ Ali ElSayed ${ }^{b}$; Sobhy Mohamed; Hanafy Hifny ${ }^{b}$ \\ ${ }^{a}$ Department of Physiology, Faculty of Veterinary Medicine, Mansoura University, Egypt. \\ ${ }^{\mathrm{b}}$ Department of Theriogenology, Faculty of Veterinary Medicine, Zagazig University, Egypt. \\ *Correspondence: elseady4370@yahoo.com
}

\begin{abstract}
Metabolic disorders cause severe losses to dairy farmers, with adverse effects on milk yield and dairy cattle's reproductive efficiency. Hypocalcemia is the most common metabolic defects affecting dairy cows during transition periods and affecting reproductive efficiency. This research aimed to study the relationship between the most common metabolic disorder (hypocalcemia) and reproductive efficiency in dairy cows. Fifty-three dairy cows were grouped based on blood calcium level into normal and subclinical hypocalcemic cows. Body condition scours and reproductive disorders were recorded. Moreover, reproductive efficiency was reported until 280 days in milk. Results reported a significant increase and positive correlation between reproductive disorder (dystocia, stillbirth, retained placenta, metritis, and vaginitis) in animals suffering from subclinical hypocalcemia. These results conclude that subclinical hypocalcemia impairs reproductive efficiency in dairy cows and subsequently it lowers the benefit from dairy farming.
\end{abstract}

Keywords: milk fever, dairy cow , reproduction.

\section{Introduction}

Most pre-parturient abnormalities originate from some metabolic disturbance of elements causing clinical diseases. The metabolic disturbances as milk fever can be measured through low serum ca concentration (Duffied, 2006). Borsberry and Dobson (1989) suggested that hypocalcemia might reduce fertility in dairy cows. Where, it affects uterine muscle contractility, prolongs uterine involution, and decreases blood flow to the ovaries; moreover, it has indirect effects on fertility through dystocia, retained placenta, and endometritis (Jonsson and Daniel 1997).

Whiteford and Sheldon (2005) reported that cows with clinical milk fever had large size of the gravid and non-gravid uterine horn between 2 weeks and 6 weeks post-partum and a significantly reduced luteolysis of corpus luteum than normal cows. Furthermore, Karmgarpour et al. (1999) found that, cows with milk fever have fewer ovulatory sized follicles than normal cows.

Sub-clinical hypocalcemia (blood calcium concentration falling below $8 \mathrm{mg} / \mathrm{dl}$ ) occurs in up to $50 \%$ of older cows during the days immediately following calving (Horst et al. 2003). The decline in blood calcium concentration around parturition represents a breakdown in the calcium hemostatic mechanisms of the body (Duffied,2006).

Subclinical milk fever is supposed to be a significant predisposing factor that increases other transition cow disorders. As cows with milk fever were up to 8 times more likely to develop mastitis in the following season of lactation, more reliable to develop dystocia and retained placenta three-time, and two to four times more affected by abomasal displacement (Mulligan et al., 2006).

In the same respect, hypocalcemia has indirect effects on fertility that mediated through dystocia, endometritis, and retained placenta (Mulligan et al., 2006). Overall, it shows that cows with clinical milk fever may be at high risk of infertility compared with their healthy herd mates. Therefore, this study aimed to investigate the relationship between blood calcium level and some reproductive performance of dairy cows.

\section{Materials and methods}

\subsection{Animals}

This study was carried out on 53 dairy cows belonged to large dairy farms (Alexandria Copenhagen) with a total number of 1100 dairy cows, starting from December 2012 to February 2014. The animals were 2.5 -14 years old (1 to 10 lactations). The average milk production per cow was about 9 tons/season. They were milked three times daily. The animals were free from brucella, leucosis, and TB according to the certificate of origin and the regular veterinary checks performed. Animals were fed TMR to fulfill the dairy cow's requirements, according to NRC (2009). All cows were clinically examined in a close-up period (starting from 260 days gestation up to 2 weeks postpartum). Blood samples were collected at day 270 gestation and 10 day post-partum to classify cows into normal cows $(8-12.4 \mathrm{mg} / \mathrm{dl})$ and subclinical hypocalcemic cows $(6-8 \mathrm{mg} / \mathrm{dl})$ according to Horest et al. (2003).

\subsection{Body condition score}

Animals were evaluated for body condition score (BCS) by eye observation and palpation in the close-up period, according to Edmonson.et.al. (1989). The body condition score was determined on a scale from 1 to 5 with a 0.25 Unit precision where one is extremely thin, and five is extremely fat.

\subsection{Sampling and grouping of animals}

Out of 53 cows, blood samples were taken only from 28 cows at 270 
DCC and after delivery on day ten post-partum. Blood was taken from the milk vein without anticoagulant. The samples were cooled on ice-packs soon after collection. The samples were centrifuged within $3 \mathrm{hr}$, at $3500 \mathrm{rpm}$ for $10 \mathrm{~min}$. Obtained sera were frozen at $20{ }^{\circ} \mathrm{C}$ until analysis.

Based on the determined Ca level, the studied cows were classified into normal cows $(8-12.4 \mathrm{mg} / \mathrm{dl})$ and subclinical hypocalcemia cows (6-8 mg/dl) (Horest et al.,2003).

\subsection{Serum biochemical assays}

Calcium, phosphorous, and magnesium levels were determined using a spectrophotometer (GENWAY multichannel spectrophotometer UK.). At Mansoura university central lab using VITRO SCIENT kits Egypt. BHBA was also determined using the Precision Xtra meter (Abbott Laboratories, Abbott Park, IL).

\subsection{Reproductive program}

Fresh studied animals at 17-18 DIM were subjected to pre-synch. Program to be inseminated at 53-57 DIM. (Michael and Thomas, 2005).

17-18 DIM

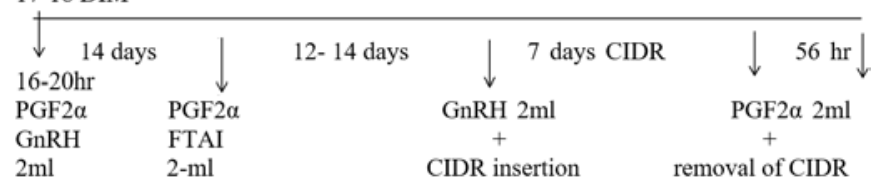

PGF2 $\alpha$ (Estrumate, $1 \mathrm{ml}$ contains $250 \mu \mathrm{g}$ cloprostenol, shering plough company); GnRH (Receptal, $1 \mathrm{ml}$ contains $4.0 \mu \mathrm{g}$ buserelin, intervet company); CIDR (controlled intravaginal device release, each insert contains $1.38 \mathrm{gm}$ of progesterone, Pfizer company); FTAI (fixed-time artificial insemination).

The same veterinarian mostly carried out artificial insemination at the due time of the program. Animals diagnosed non-pregnant in the pregnancy diagnosis were subjected to re-synch. They were using ovisynch. With CIDR until conception. (Michael and Thomas, 2005).

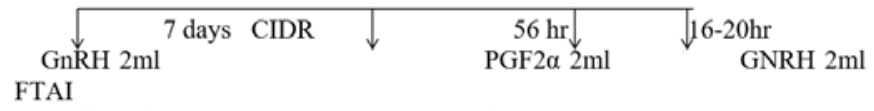

CIDR insertion CIDR removal

\subsection{Estrous detection}

Estrous was detected by well-trained persons continuously throughout the day and night. Animals returned to heat were inseminated by the same veterinarian. Other non-returned cows were checked for pregnancy by rectal palpation at 50 days post insemination. Conception rate, services per conception, and days open were also calculated. This breeding management program continued until all the animals conceived or reached a DIM of more than 280. Reproductive data of these animals not conceived by 280 days DIM were excluded from the statistical analysis.

\subsection{Statistical analysis}

Statistical analysis was performed using the Statistical Package for Social Sciences version 22.0 (IBM Corp., Armonk, NY, USA). To assess whether there is a significant correlation between metabolic and reproductive disorders, a chi-square-test $\left(\chi^{2}\right)$ was performed. The significance of mean differences among groups was tested using independent samples T-test. Levene's test analyzed the homogeneity of variances. Results are expressed as mean \pm standard error of the mean (SEM). The value of $P<0.05$ was used to indicate the statistical significance, and $\mathrm{P}<0.001$ indicates a highly significant difference.

\section{Results}

\subsection{The Relationship between BCS and Ca Level}

Table (1) shows the mean values of blood Ca concentrations in
Holstein Friesian cows before and after parturition. Serum Ca levels were lower than normal before parturition in all cows with different body score. These values ranged between $6.11 \pm 0.2$ and $6.78 \pm 0.54$ $\mathrm{mg} / \mathrm{dl}$ compared to a normal range of Ca level (8-12.4 mg/dl) (Oetzel 2004). These levels of Ca were increased after calving and ranged between $7.23 \pm 0.88$ to $8.67 \pm 1.15 \mathrm{mg} / \mathrm{dl}$. On day 10 post-partum in all studied cows, there was no significant variation between BCS and calcium level.

Table 1. Serum Ca concentrations (mg/dl) in peripartum Holstein Friesian cows concerning different Body condition score (BCS).

\begin{tabular}{|c|c|c|c|}
\hline BCS & $\begin{array}{l}\text { Number } \\
\text { of cows }\end{array}$ & $\begin{array}{l}\text { Ca level at } 270 \\
\text { DCC }\end{array}$ & $\begin{array}{l}\text { Ca level } 10 \text { days } \\
\text { after parturition }\end{array}$ \\
\hline 3.25 & 4 & $6.139852 \pm 1.2$ & $7.23 \pm 0.88$ \\
\hline 3.5 & 4 & $6.11 \pm 0.2$ & $8.27 \pm 1.49$ \\
\hline 3.75 & 7 & $6.53 \pm 0.45$ & $7.49 \pm 0.73$ \\
\hline 4 & 10 & $6.78 \pm 0.54$ & $7.89 \pm 0.57$ \\
\hline 4.5 & 3 & $6.62 \pm 1.2$ & $8.67 \pm 1.15$ \\
\hline P. value & & $0.996 \mathrm{NS}$ & $0.934 \mathrm{NS}$ \\
\hline F. value & & 0.037 & 0.19 \\
\hline
\end{tabular}

\subsection{The relationship between $\mathrm{Ca}, \mathrm{P}$, and $\mathrm{Mg}$}

Table (2) shows the mean values of phosphorus and magnesium in normal and subclinical hypocalcaemic Holstein Frisian cows. The mean Ca level of normal cows ( $\mathrm{n}=15)$ was $9.62 \pm 0.39 \mathrm{mg} / \mathrm{dl}$. The corresponding means of phosphorous (normal range 4.3-7.8 mg/dl.) and magnesium levels (normal range 1.7-3 mg/dl.) (Merck Veterinary Manual. 2011), were $5.96 \pm 0.56 \mathrm{mg} / \mathrm{dl}$. and $4.33 \pm 0.58 \mathrm{mg} / \mathrm{dl}$, respectively. On the other hand, the mean Ca level of subclinical hypocalcaemic cows $(\mathrm{n}=13)$ was $6.59 \pm 1.37 \mathrm{mg} / \mathrm{dl}$. At the same time, the corresponding mean of $\mathrm{P}$ and $\mathrm{Mg}$ levels were $2.59 \pm 0.78 \mathrm{mg} / \mathrm{dl}$ and $3.68 \pm 0.68 \mathrm{mg} / \mathrm{dl}$, respectively.

Table 2. Mean serum values of calcium, phosphorous, and magnesium ten days post-partum in Holstein Friesian cows.

\begin{tabular}{lllll}
\hline & $\begin{array}{l}\text { Number } \\
\text { Of } \\
\text { Cows }\end{array}$ & $\begin{array}{l}\text { Ca level } \\
\text { Ref. range } \\
(8-12 \mathrm{mg} / \mathrm{dl} .)\end{array}$ & $\begin{array}{l}\text { P level } \\
\text { Ref. range } \\
(4.3-7.8 \mathrm{mg} / \mathrm{dl} .)\end{array}$ & $\begin{array}{l}\text { Mg level } \\
\text { Ref. range } \\
(1.7-3 \mathrm{mg} / \mathrm{dl} .)\end{array}$ \\
\hline Normal Ca level cows & 15 & $9.62 \pm 0.39 \mathrm{a}$ & $5.96 \pm 0.56 \mathrm{a}$ & $4.33 \pm 0.58$ \\
$\begin{array}{l}\text { Subclinical hypocalcaemic } \\
\text { cows }\end{array}$ & 13 & $6.59 \pm 1.37 \mathrm{~b}$ & $2.59 \pm 0.78 \mathrm{~b}$ & $3.68 \pm 0.68$ \\
\hline
\end{tabular}

Data were presented as mean \pm SEM. Values in the same columns with different letters ( $\mathrm{a}$ and $\mathrm{b}$ ) differ significantly at $\mathrm{P} \leq 0.05$.

\subsection{Relationship between hypocalcemia and reproductive disorders}

Cows with normal blood Ca level at day 10 post-partum showed $7.6 \%$ dystocia and $33 \%$ in cows with subclinical hypocalcemia (Table 3). Stillbirth is not recorded in animals with normal Ca level while it reached $20 \%$ in hypocalcemic cases. Regarding the percentage of RP $40 \%$ of cows showed RP. In subclinical hypocalcaemic cases, metritis, on the other hand, was higher $53.3 \%$ in cases with subclinical hypocalcemia in contrast to $15.4 \%$ in animals of ordinary Ca values. There are no cases observed in normal Ca concentration concerning vaginitis but increased to a higher level (20\%) in animals with subclinical hypocalcemia. 
Table 3. The relationship between metabolic and reproductive disorders 10 days post-partum in Holstein Friesian cows.

\begin{tabular}{lll}
\hline $\begin{array}{l}\text { Reproductive } \\
\text { disorder }\end{array}$ & $\begin{array}{l}\text { Cows with normal } \\
\text { Ca. level }(\mathrm{n}=13)\end{array}$ & $\begin{array}{l}\text { Cows with subclinical } \\
\text { hypocalcemia }(\mathrm{n}=15)^{*}\end{array}$ \\
\hline Dystocia & $7.6 \%(\mathrm{n}=1) \mathrm{a}$ & $33 \%(\mathrm{n}=5) \mathrm{b}$ \\
Stillbirth & $0 \%$ & $20 \%(\mathrm{n}=3)$ \\
Retained placenta & $0 \% \mathrm{~b}$ & $40 \%(\mathrm{n}=6) \mathrm{a}$ \\
Metritis & $15.4 \%(\mathrm{n}=2)$ a & $53.3 \%(\mathrm{n}=8) \mathrm{b}$ \\
Vaginitis & $0 \%$ & $20 \%(\mathrm{n}=3)$ \\
\hline
\end{tabular}

Values in the same row with different letters (a and b) differ significantly at $\mathrm{P} \leq 0.05$.

\subsection{Relationship between hypocalcemia and reproductive efficiency}

Table (4) shows the effect of subclinical hypocalcemia post-partum on reproductive efficiency. Days open were $117.75 \pm 6.2$ and $211.78 \pm 3.7$ in normal and hypocalcemic cows, respectively. There was a significant $(\mathrm{p} \leq 0.01)$ increase in days open in hypocalcemic cows. Services per conception in cows were $2.16 \pm 0.21$ in average and $3.57 \pm 0.35$ in subclinical hypocalcaemic cows. There was a significant increase in the number of services in hypocalcemic cows $(\mathrm{p} \leq 0.05)$.

Table 4. The Relationship between post-partum hypocalcemia and reproductive efficiency in Holstein Friesian cows.

\begin{tabular}{llll}
\hline $\begin{array}{l}\text { Reproductive } \\
\text { performance }\end{array}$ & $\begin{array}{l}\text { Subclinical } \\
\text { hypocalcemia }\end{array}$ & $\begin{array}{l}\text { Normal } \\
\text { calcium level }\end{array}$ & $\begin{array}{l}\text { P- } \\
\text { value }\end{array}$ \\
\hline Number of animals & 15 & 13 & \\
Days open & $211 \pm 5.17 \mathrm{a}$ & $117 \pm 4.71 \mathrm{~b}$ & 0.001 \\
Number of services per & $3 \pm 0.7 \mathrm{a}$ & $2.2 \pm 0.58 \mathrm{~b}$ & 0.045 \\
conception & & & \\
\hline
\end{tabular}

Data were presented as mean \pm SEM. Values in the same raw with different subscripts differ significantly at $\mathrm{P} \leq 0.05$.

\subsection{The relationship between hypocalcemia and dystocia}

Regarding the effect of hypocalcemia at 270 DCC on dystocia, there was a significant positive correlation between hypocalcemia and dystocia, as showed in Table (5).

Table 5. The relationship between hypocalcemia and dystocia in Holstein Friesian cows.

\begin{tabular}{lccccccc}
\hline & No & \multicolumn{2}{c}{ Non-dystocia } & \multicolumn{2}{c}{ Dystocia } & $\chi^{2}$ & P-value \\
& . & No & $\%$ & No & $\%$ & & \\
\hline No & 13 & 12 & $92.31 \%$ & 1 & $7.69 \%$ & 3.3 & 0.016 \\
hypocalcemia & & & & & & 7 & \\
Hypocalcemia & 15 & 10 & $66.67 \%$ & 5 & $33.33 \%$ & & \\
\hline
\end{tabular}

\subsection{The relationship between hypocalcemia and retained placenta}

There was a significant $(\mathrm{P} \leq 0.05)$ relationship between hypocalcemia post-partum and retained placenta (Table 6).

Table 6. The relationship between hypocalcemia and RP in Holstein Friesian cows.

\begin{tabular}{|c|c|c|c|c|c|c|c|}
\hline \multirow[t]{2}{*}{ Hypocalcemia } & \multirow[t]{2}{*}{ No. } & \multicolumn{2}{|c|}{$\begin{array}{l}\text { No-hypocalcemia } \\
(\mathrm{n}=13)\end{array}$} & \multicolumn{2}{|c|}{$\begin{array}{l}\text { Hypocalcemia } \\
\qquad(n=15)\end{array}$} & \multirow[t]{2}{*}{$\chi^{2}$} & \multirow[t]{2}{*}{$\begin{array}{l}\text { P- } \\
\text { value }\end{array}$} \\
\hline & & No & $\%$ & No & $\%$ & & \\
\hline Non- RP & 22 & 13 & $100 \%$ & 9 & $60 \%$ & \multirow{2}{*}{3.94} & \multirow{2}{*}{0.047} \\
\hline $\mathrm{RP}$ & 6 & 0 & $0.0 \%$ & 6 & $40 \%$ & & \\
\hline
\end{tabular}

\subsection{The relationship between hypocalcemia and metritis:}

Table (7) shows a significant $(\mathrm{P} \leq 0.05)$ relationship between postpartum hypocalcemia and metritis.
Table 7. The Relationship between hypocalcemia and metritis in Holstein Friesian cows.

\begin{tabular}{lcllllll}
\hline & No. & \multicolumn{2}{l}{$\begin{array}{l}\text { No-hypocalcemia } \\
(\mathrm{n}=13)\end{array}$} & \multicolumn{2}{l}{$\begin{array}{l}\text { Hypocalcemia } \\
(\mathrm{n}=15)\end{array}$} & $\chi^{2}$ & $\begin{array}{l}\text { P- } \\
\text { value }\end{array}$ \\
& & No. & $\%$ & No. & $\%$ & & \\
\hline Non-metritis & 18 & 11 & $84.6 \%$ & 7 & $46.7 \%$ & 3.01 & 0.031 \\
Merits & 10 & 2 & $15.4 \%$ & 8 & $53.3 \%$ & & \\
\hline
\end{tabular}

\subsection{The relationship between hypocalcemia and vaginitis:}

Table (8) shows a significant $(\mathrm{P} \leq 0.05)$ Relationship between postpartum hypocalcemia and vaginitis.

Table 8. The relationship between hypocalcemia and vaginitis in Holstein Friesian cows.

\begin{tabular}{llllllll}
\hline & No & \multicolumn{2}{l}{$\begin{array}{l}\text { No-hypocalcemia } \\
(\mathrm{n}=13)\end{array}$} & $\begin{array}{l}\text { Hypocalcemia } \\
(\mathrm{n}=15)\end{array}$ & $\chi^{2}$ & P-value \\
& & No. & $\%$ & No. & $\%$ & & \\
\hline $\begin{array}{l}\text { No } \\
\text { Vaginitis }\end{array}$ & 25 & 13 & $100 \%$ & 12 & $80 \%$ & 4.94 & 0.026 \\
Vaginitis & 3 & 0 & $0.0 \%$ & 3 & $20 \%$ & & \\
\hline
\end{tabular}

\section{Discussion}

The transition period is critical in dairy cows' breeding cycle, affecting subsequent production, health, and reproductive performance. The most common disorders in a transition period observed in dairy cattle in this study include milk fever, dystocia, retained placenta, and ketosis. This study found that Ca serum concentrations were lower in animals with varying BCS before parturition. This lower Ca level could be due to the -ve DCAD ratio. On the other hand, animals at 10 days after parturition had the borderline of normal $\mathrm{Ca}$ level and this could be due to $\mathrm{Ca}$ containing drench after calving. In contrast, Ostergaard et al. (2003) reported that dairy cows with the over-condition score at calving are up to four times susceptible to develop milk fever. Moreover, Mulligan et al. (2006) suggested that higher BCS cows at delivery have higher Ca. Besides, over scoring dairy cows have a reduced feed intake relative to thinner cows in the last week pre-calving. This may reduce their feed intake of Ca to the levels which predispose them to milk fever. These authors did not report whether they use the DCAD ratio or not.

There was a decline in phosphorus serum levels in the hypocalcemic cows with normal magnesium levels. In agreement with this study, Goff (1999) stated that phosphorous could negatively impact calcium. Phosphorus might play an essential role in milk fever, where animals with a high level of phosphorus could be risky to develop milk fever. As phosphorus level is not as tightly regulated as calcium, both are regulated directly by $1,25(\mathrm{OH}) 2$ D3 and indirectly by the parathyroid hormone/calcium negative feedback loop (Goff 1999). While magnesium is an essential element, about $70 \%$ of body magnesium is present in bone, and the expected balance is found in soft tissue. It maintains membrane stability. Hence it is essential to skeletal muscle function, cardiac muscle function, and nervous tissue function. Magnesium is essential in the synthesis of 1,25(OH)2 D3 and in the release of parathyroid hormone. In hypomagnesemia cases, bone and kidney are less responsive to PTH (Goff 2000; Sampson et al. 1983). Wang and Beede (1992) showed that non-pregnant, non-lactating cows fed a high mag. Diet had lower renal calcium excretion than those fed a diet with low magnesium. Contreras et al. (1982) and van de Braak et al. (1987) proved low calcium mobilization in hypomagnesemia cattle. $\mathrm{Mg}$ is an essential cation for many metabolic processes and interestingly shows wide variability. A wide range may impact a regional influence on metabolic syndromes reported as influenced by soil profiles, cropping practices, and climatic condition variability (Kevin Lager and 
Ellen Jordan, 2012). Magnesium homeostasis is based on an optimal supply from alimentary sources; accordingly, $\mathrm{Mg}$ concentration is dependent on $\mathrm{Mg}$ absorption in the rumen (Fontenot et al., 1989; Kurćubić et al., 2010).

Strong association has been reported between metabolic and reproductive disorders. In this regard dystocia, stillbirth, RP, metritis and vaginitis showed $33 \%$ vs. $7.6 \%, 20 \%$ vs. $0 \%, 40 \%$ vs. $0 \%$, $53.3 \%$ vs. $15.4 \%$ and $20 \%$ vs. $0 \%$ in cows with subclinical milk fever and normal cows, respectively. Statistical analysis of ca. level in cows suffered from dystocia, RP, metritis and vaginitis revealed high significant correlation. Several studies indicated an increased incidence of dystocia in cows with milk fever than normal cows (Curtis et al., 1983; Erb et al., 1985, Correa et al., 1993 and Kimura et al. 2006). Regarding the association between subclinical milk fever and stillbirth, our results showed a high incidence. This was due to calves delivered in dystocia are compromised, i.e., aromatized, lowered temp., lazy, and a downer for an extended period with hypoxia (Mortimer R.,1997).

Regarding the effect of milk fever and RP, double the odds of RP occurring was reported by (Erb et al., 1985). Furthermore, a sizeable indirect effect of milk fever on RP was cleared by (Correa et al., 1993). Houe et al. (2001) also cited an increased risk of RP Following milk fever. Melendez et al. (2004) reported a significantly lower Ca level associated with RP. Kimura et al., (2006) observed a clear link between milk fever and RP. Moreover, metritis and vaginitis percentage are higher in cases showed hypocalcemia. In this respect, (Kimura et al., 2006), Whiteford and Sheldon 2005), and (Borsbery and Dobson, 1989) reported a significant link between milk fever, immunosuppression, endometritis, and retarded uterine involution. Furthermore, vaginitis incidence is high due to bad managemental practice evidenced in the farm. In addition to the lower ca. levels recorded.

Our findings also indicated that days open revealed mean values of $211.78 \pm 3.7$ vs. $117.75 \pm 6.2$ for cows with hypocalcemia and those with normal Ca level, respectively. Service/conception also shows $3 \pm 0.7$ vs. $2.2 \pm 0.58$ for hypocalcemia and normal cows, respectively. The hypocalcemic cows showed significant correlation with days open and service per conception. Statistical analysis of correlation cleared significant values $\mathrm{p} \leq 0.05$ for days open and $\mathrm{p} \leq$ 0.05 for $\mathrm{S} / \mathrm{C}$. Metritis on the other hand shows a high significant $(\mathrm{p} \leq$ 0.01 ) effect on both days open and S/C. Furthermore, vaginitis showed a high significant $(\mathrm{p} \leq 0.01)$ effect on days open and $\mathrm{S} / \mathrm{C}$. These findings may be due to the increased incidence of RP, metritis, and vaginitis recorded in hypocalcemia cows. The same findings were recorded by Jonsson and Daniel (1997). They recorded an indirect effect of hypocalcemia on fertility through dystocia, endometritis, and retained placenta. Also Borsberry and Dobson, (1989) suggested that milk fever lowered fertility in dairy cows due to its effect on uterine muscle contraction, slower uterine involution, reduced blood flow to the ovaries, and increase S/C. Whiteford and Sheldon (2005) also reported a decrease in conception rate to the first service in a herd associated with lowered Ca concentration. Furthermore, Kamgarpour et al. (1999) reported fewer ovulatorysized follicles affected with subclinical hypocalcemic cows at days 15 , 30, and 45 post-partum than normal cows.

It could be concluded that adjusting BCS before parturition and applying the drenching program will decrease the incidence of metabolic disorders and increase reproductive performance.

\section{Conflict of interest}

The authors declare that they have no conflict of interest.

\section{References}

Borsberry, S. and Dobson, H. (1989). Periparturient diseases and their effect on reproductive performance in five dairy herds. Veterinary Record 124: 217-219.

Contreras, P.A., R. Manston and B.F. Samson (1982), Calcium homeostasis in hypomagnesaemic cattle. Res. Vet. Sci. 33:10-16.

Correa, M.T., Erb, H. and Scarlett, J. (1993). Path analysis for seven post-partum disorders in Holstein cows. Journal of Dairy Science 76:1305-1312.

Curtis, C.R., Erb, H.N., Sniffen, C.J., Smith, R.D., Powers, P.A.,Smith, M.C., White, M.E., Hilman, R.B. and Pearson, E.J. (1983).Association of parturient hypocalcaemia with eight periparturient disorders in Holstein cows. Journal of the American Veterinary medical Association 183: 559-561.

Dufflied, T.F. (2006). Epidemiology of subclinical production diseases in dairy cows with an emphasis on ketosis. In: Proc. of $12^{\text {th }}$ Intl. Conf. on Production diseases in farm animals by Joshi, N. and Herdt, T.H.,. 126-135.

Edmonson, A. J., I. J. Lean, L. D. Weaver, T. Farver, and G. Webster. (1989). A body condition scoring chart for Holstein dairy cows. J. Dairy Sci. 72:68-78.

Erb, H.N., Smith, R.D., Oltenacu, P.A., Guard, C.L., Hilman, R.B., Powers, P.A., Smith, M.C. and White, M.E. (1985). Path model of reproductive disorders and performance, milk fever, mastitis,milk yield and culling in Holstein cows. Journal of Dairy Science 68:3337-3349.

Fontenot, J. F., V. C. Allen, G. E. Bunce and J. P. Goff, 1989. Factors influencing magnesium apsorption and metabolism in ruminants. J. Anim. Sci., 67: 3445-3455.

Goff, J.P. (1999), Treatment of calcium, phosphorus and magnesium balance disorders. Vet. Clin. North Am. Food Anim. Pract. 15:619-639.

Goff, J.P. (2000), Pathophysiology of calcium and phosphorus disorders. Vet. Clin. North Am. Food Anim. Pract. 16:319-337.

Horest, R.L.,J.P.Goff and B.Mccluckey,(2003).Prevalence of subclinical hypocalcaemia in US. Dairy operations. Journal of Dairy Science 86 (Suppl. 1), 247.

Houe, H., Ostergaard, S., Thilsing-Hansen, T., Jorgensen, R.J.,Larsen, T., Sorensen, J.T., Agger, J.F. and Blom, J.Y. (2001). Milkfever and subclinical hypocalcaemia - an evaluation of parameters on incidence risk, diagnosis, risk factors and biological effects as input for a decision support system for disease control. Acta Vet. Scand. 42:1-29.

Jonsson, N.N. and Daniel, R.C.W. (1997). Effect of hypocalcaemia in blood flow to the ovaries of sheep. Journal of the American Veterinary Association 44: 281-287.

Kamgarpour, R., Daniel, R.C.W., Fenwick, D.C., McGuigan, K. and Murphy, G. (1999). Post-partum subclinical hypocalcaemia and effects on ovarian function and uterine involution in a dairy herd. Veterinary Journal 158: 59-67.

Kevin Lager and Ellen Jordan,(2012.) The Metabolic Profile for the Modern Transition Dairy Cow. Mid-South Ruminant Nutrition Conference, Grapevine, Texas.

Kimura, K., Reinhardt, T.A. and Goff, J.P. (2006). Parturition and hypocalcaemia blunts calcium signals and immune cells of dairy cattle. Journal of Dairy Science 89: 2588-2595.

Kimura, K., Reinhardt, T.A. and Goff, J.P. (2006). Parturition and hypocalcaemia blunts calcium signals and immune cells of dairy cattle. Journal of Dairy Science 89: 2588-2595.

Kurćubić, V., Z. Ilić, M. Vukašinović and R. Đoković, 2010. Effect of 
Dietary Supplements of Sodium Bicarbonate on Tissue Calcium (Ca) and Magnesium (Mg) Levels in Beef Cattle. Acta Agriculturae Serbica, 29 (15) : 55-76.

Melendez, P., Donovan, G.A., Risco, C.A. and Goff, J.P. (2004). American Journal of Veterinary Research 65:1071-7076.

Merck Veterinary Manual. 2011. Metabolic disorders. Hepatic lipidosis. Fatty liver disease of cattle. Accessed 4/5/2012.

Michael L.D. and Thomas W.G. (2005), Handbook of estrous synchronization. Western association of agriculture experiment, Station Directors. (WRP 014).

Mortimer R.G. (1997). Calving Difficulty, Proceedings The Range Beef Cow Symposium XV December 9, 10 and 11, 1997, Rapid City, South Dakota.

Mulligan, F.J., O'Grady, L., Rice, D.A. and Doherty, M.L. (2006). A herd health approach to dairy cow nutrition and production diseases of the transition cow. Animal Reproduction Science 96: 331-353.

NRC (2009). Nutrient requirements of dairy cattle, Washington, D.C. nutritional academy press

Oetzel, G.R., (2004). Monitoring and testing dairy herds for metabolic disease. Veterinary Clinics of North America-Food Animal Practice 20, 651-674.

Ostergaard, S., Sorensen, J.T. and Houe, H. (2003). A stochastic model simulating milk fever in a dairy herd. Preventive Veterinary Medicine 58:125-143.

Sampson, B.F., R. Manston and M.J. Vagg (1983), Magnesium and Milk Fever. Vet. Rec. 112:447-449.

Van de Braak, A.E., A.T. Van't Klooster and A. Malestein (1987), Influence of a Deficient Supply of Magnesium during the Dry Period on the Rate of Calcium Mobilization by Dairy Cows at Parturition. Res. Vet. Sci. 42:101-108.

Wang, C. and D.K. Beede (1992), Effects of Diet Magnesium on Acid-Base Status and Calcium Metabolism of Dry Cows Fed Acidogenic Salts. J. Dairy Sci. 75:829-836.

Whiteford, L.C. and Sheldon, I.M. (2005). Association between clinical hypocalcaemia and post-partum endometritis. Veterinary Record 157: 202-204. 